\title{
Reactividad y aptitud a la cocción de crudos de cemento con elevados contenidos
}

en manganeso

\section{Reactivity and burnability of cement raw materials with high manganese content}

Fecha de recepción: 18 mayo 1988

\section{RESUMEN}

Se ha comprobado que contenidos elevados de manganeso en el crudo provoca una modificación significativa en la composición mineralógica del clínker. Se desarrollan las fases no tradicionales $2 \mathrm{CaO}_{\mathrm{MnO}}$ y $\mathrm{Ca}_{2} \mathrm{AlMnO}_{5}$, y se puede llegar, incluso, a inhibir la formación de aluminato tricálcico.

El manganeso tiene un comportamiento fundente muy similar al jugado por el hierro en los crudos tradicionales, por lo que la incorporación de óxidos de manganeso al crudo produce una alteración significativa en los módulos tradicionales (LSF, Ms y Mf). Esto tiene como consecuencia inmediata un gran incremento en la proporción de fase instersticial en los clínkeres producidos.

\author{
F. PUERTAS, M. ${ }^{a}$ T. BLANCO-VARELA, T. VAZQUEZ \\ IETCC/CSIC
}

Serrano Galvache, s.n. 28033 Madrid/España

\section{SUMMARY}

It has been verified that high manganese content in raw mixes causes alters the mineralogical composition of clinkers. New phases like $2 \mathrm{CaO} . \mathrm{MnO}_{2}$ and $\mathrm{Ca}_{2} \mathrm{AlMnO}_{5}$ are developed and $C_{3} A$ formation can be inhibited.

Manganese is a flux similar to iron in the traditional raw mixes. The presence of manganese will modify the expressions of the lime saturation factor (LSF), silica modulus (Ms) and aluminium modulus (Mf). This has as consequence an increase of the proportion of intersticial phase in the obtained clinkers.

\section{INTRODUCCION}

El contenido en óxidos de manganeso en el cemento portland, no excede del 0,1\%.

Proporciones del 1-3 \% e incluso superiores en estos óxidos se pueden encontrar cuando las escorias de alto horno son utilizadas como materia prima para la fabricación de cemento (1).

Determinar el comportamiento de componentes minoritarios, como los óxidos de manganeso, en el proceso de clinkerización tienen un gran interés no sólo desde un punto de vista científico sino también desde un punto de vista tecnológico.

Existen pocos estudios relativos al efecto que el manganeso y sus óxidos ejercen sobre el proceso de formación del clinker. Algunos de los más relevantes se detallan a continuación.

\section{INTRODUCTION}

The content of manganese oxides in portland cement generally do not exceed $0,1 \%$. However, contents of $1-3 \%$ an ever more can be found when blast-furnace slags are used as raw materials for the making of the cement (1).

To determine the behaviour of minor components on clinkerization process has a big interest, not only of the scientifical point of view besides tecnological one.

Few reseach works study the effect of manganese and their manganese oxides on the process of making of clinker. Some of them are going to be described now. 
Kennerly (2) comprobó que en cementos con contenidos inferiores a un $4 \%$ en $\mathrm{Al}_{2} \mathrm{O}_{3}$ y alrededor de un $50 \%$ en $\mathrm{C}_{3} \mathrm{~S}$, al añadir un $0,2 \%$ de $\mathrm{Mn}_{2} \mathrm{O}_{3}$, se produce una reducción en el contenido de $\mathrm{C}_{3} \mathrm{~A}$, lo cual afecta a las resistencias iniciales del cemento.

En otros trabajos de investigación (3) (4) se ha demostrado que en clínkeres normales que contienen fase ferrítica, el manganeso se incorpora a dicha fase, haciéndolo en menor proporción en aluminatos y silicatos. La presencia de $\mathrm{Mn}_{2} \mathrm{O}_{3}$ en la fase intersticial aumenta, según estos autores, su cantidad y actividad ya que se produce una disminución en la viscosidad del fundido (3).

Se ha demostrado que las reacciones de formación de silicatos (5) (6) se ven aceleradas por la acción conjunta de $\mathrm{BaO}$ y $\mathrm{Mn}_{2} \mathrm{O}_{3}$. La completa combinación del $\mathrm{CaO}$ se consigue a temperaturas $20-40^{\circ} \mathrm{C}$ inferiores a las necesarias en clínkeres exentos de estos óxidos. A esto hay que añadir un incremento en la porosidad y una mejor cristalización de la alita y la belita.

El objetivo fundamental planteado en el presente trabajo fue determinar el comportamiento reactivo y la aptitud a la cocción de crudos de cemento portland con elevados contenidos en manganeso.

\section{PARTE EXPERIMENTAL}

Se preparó un crudo patrón, denominado A, consistente en caliza, escoria cristalizada de alto horno y $\mathrm{Fe}_{2} \mathrm{O}_{3}$, con una composición química definida (LSF $=98, \mathrm{Ms}=2,18$ y $\mathrm{Mf}=$ $=2,2$ ). El análisis químico de dicho crudo aparece recogido en la Tabla I. A este crudo se adicionó manganeso, en forma de $\mathrm{Mn}(\mathrm{COO})_{2} .2 \mathrm{H}_{2} \mathrm{O}$, en proporciones del 1, 2 y $5 \%$. En la Tabla II se muestran las composiciones preparadas.

El comportamiento térmico de estos crudos se estudió por ATD siendo los calentamientos programados a una velocidad constante de $8^{\circ} \mathrm{C} / \mathrm{min}$, hasta una temperatura máxima de $1.500^{\circ} \mathrm{C}$. Así mismo, se realizaron tratamientos isotermales a $1.350^{\circ}, 1.400^{\circ} \mathrm{y}$ $1.450^{\circ} \mathrm{C}$ permaneciendo las muestras en el horno durante 30 minutos a cada temperatura.

Los clínkeres obtenidos fueron analizados por difracción de rayos $X$ y microscopía óptica. Se realizaron, también, análisis de $\mathrm{CaO}$ libre (7), y algunos clínkeres fueron atacados por el método de Takashima (8) con el objeto de poder estudiar la composición mineralógica de la fase intersticial.
Kennerly (2) showed that, in cements with $\mathrm{Al}_{2} \mathrm{O}_{3}$ contents less than $4 \%$ and with about $50 \% \mathrm{C}_{3} \mathrm{~S}$, adding the amount of $\mathrm{Mn}_{2} \mathrm{O}_{3}$ about $0,2 \%$ reduced the $C_{3} A$ content which affected the early strength of cement.

Studies of portland clinkers with a high content of manganese (3) (4), have concluded that manganese is preferentially incorporated in the ferrite phase, decreasing the proportion of manganese in the aluminate and silicates.

The presence of $\mathrm{Mn}_{2} \mathrm{O}_{3}$ in the interstitial phase increase its quantity and activity, as it decreases the liquid viscosity.

The joint action of $\mathrm{BaO}$ and $\mathrm{Mn}_{2} \mathrm{O}_{3}$ has been demostrated to accelerate the formation of silicates (5) (6). The complete combination of $\mathrm{CaO}$ finishes $20^{\circ}-40^{\circ} \mathrm{C}$ below the clinkering temperatures. Another positive effect is the increase in the porosity of the clinker and a greater crystallization of alite and belite.

The main object of the present work was to investigate the reactivity and burnability of raw maxes of portland cement clinker with high content of manganese.

\section{EXPERIMENTAL}

It was prepared an standard raw mix, called $A$ consistent of limestone, crystallized blast furnace slags and $\mathrm{Fe}_{2} \mathrm{O}_{3}$; with a constant chemical composition ( $L S F=98, M s=2,18$ and $M f=2,2)$. In Table I the chemical analysis of this raw mix is shown. Manganese was added to this raw mix as $\mathrm{Mn}(\mathrm{COO})_{2} .2 \mathrm{H}_{2} \mathrm{O}$, in proportions of $1 \%, 2 \%$ and $5 \%$. In Table II these prepared compositions are shown.

The thermal behaviour of these raw mixes were studied by DTA, being the healings at a constant rate $\left(8^{\circ} \mathrm{C} / \mathrm{min}\right.$.) until at $1.500^{\circ} \mathrm{C}$ as maximun temperature. And, also, helf at $1.350^{\circ}$, $1.400^{\circ}$ and $1.450^{\circ} \mathrm{C}$ for 30 minutes to each temperature.

The clinkers obtained were analysed by $x$-ray diffraction and optical microscopy. Analysis of free lime (7) was made and also some clinkers were studied by Takashima's method (8), in order to determine the mineralogical composition of the interstitial phase. 
TABLA I (TABLE I)

Análisis Químico del crudo A (Chemical Analysis of raw mix A)

$\mathrm{P} \cdot \mathrm{F}=25,63$
$\mathrm{SiO}_{2}=14,94$
$\mathrm{R} . \mathrm{I} \cdot=0,08$
$\mathrm{Al}_{2} \mathrm{O}_{3}=5,69$
$\mathrm{Fe}_{2} \mathrm{O}_{3}=1,43$
$\mathrm{CaO}=48,27$
$\mathrm{MgO}=3,06$
$\mathrm{SO}_{3}=0,65$
$\mathrm{Na}_{2} \mathrm{O}=0,00$
$\mathrm{~K}_{2} \mathrm{O}=0,03$

\section{RESULTADOS}

\section{Análisis Térmicos}

En la figura 1 aparecen las curvas de ATD obtenidas, durante el calentamiento y el enfriamiento, para los cuatro crudos estudiados, en el rango de $1100^{\circ} \mathrm{C}-1500^{\circ} \mathrm{C}$.

Comparando dichas curvas se observan algunas diferencias significativas.

Entre $1.150^{\circ} \mathrm{C}$ y $1.300^{\circ} \mathrm{C}$ aparecen dos picos exotérmicos, a temperaturas similares para todos los crudos $\left(1.170^{\circ} \mathrm{C}\right.$ y $\left.1.230^{\circ} \mathrm{C}\right)$. Estas señales corresponden a la formación de diversos productos por reacciones en estado sólido. A continuación, se observa una serie de señales endotérmicas, cuyas temperaturas y origen son diferentes según que los crudos contengan ó no manganeso. En el crudo A apararecen dos picos endotérmicos a $1.340^{\circ} \mathrm{C}$ y $1.370^{\circ} \mathrm{C}$, asignables a fusiones sucesivas de la masa sólida. En los crudos que contienen manganeso, la señal de $1.340^{\circ} \mathrm{C}$ se mantiene, mientras que el segundo pico se desplaza a mayores temperaturas al aumentar el $\mathrm{Mn}$ adicionado. En el crudo con $5 \%$ de manganeso, aparece incluso un tercer pico endotérmico alrededor de $1.450^{\circ} \mathrm{C}$. Durante el enfriamiento, se observa en el crudo $A$ un doble pico exotérmico de solidificación, aproximadamente a $1.260^{\circ} \mathrm{C}$ y $1.280^{\circ} \mathrm{C}$. En los crudos con manganeso aparecen varias señales exotérmicas que corresponden a la solidificación de ciertas composiciones
TABLA II (TABLE II)

Crudos con manganeso

(Raw mixes with manganese)

\begin{tabular}{|c|c|c|}
\hline $\begin{array}{c}\text { DENOMINACION } \\
\text { DEL CRUDO } \\
\text { RAW MIX }\end{array}$ & $\begin{array}{c}\text { \% CRUDO A } \\
\text { RAW MIX A (\%) }\end{array}$ & $\begin{array}{c}\text { \% Mn } \\
\text { Mn (\%) }\end{array}$ \\
\hline $\mathrm{A}$ & 100 & 0 \\
$\mathrm{~A}_{1}$ & 99 & 1 \\
$\mathrm{~A}_{2}$ & 98 & 2 \\
$\mathrm{~A}_{3}$ & 95 & 5 \\
\hline
\end{tabular}

\section{RESULTS}

\section{Thermal analysis}

The obtained curves of DTA during heating and cooling of four studied raw mixes, between $1.100^{\circ}-1.500^{\circ} \mathrm{C}$; are shown in figure 1 . To compare these curves is possible to observe some significant differences.

Between $1.150^{\circ}$ and $1.300^{\circ} \mathrm{C}$ appear two endothermic peaks, at similar temperatures for all raw mixes $\left(1.170^{\circ}\right.$ and $\left.1.230^{\circ} \mathrm{C}\right)$. These signals are due to the formation of some products by solid state reactions. As follows, there are a serie of endothermics peaks, which temperatures and origin are differents according to raw mixes have or not manganese. In raw mix $A$ appear two endothermic peaks at $1.340^{\circ}$ and $1.370^{\circ}$, dues to succesive meltings of solid composition. In raw mixes with high manganese content, the peak at $1.340^{\circ} \mathrm{C}$ is constant, but the second peak goes at higher temperatures as increase the $\mathrm{Mn}$ added. In raw mix with $5 \%$ of manganese appears, even, a third endothermic peak at $1.450^{\circ} \mathrm{C}$.

During cooling, the raw mix A shows a double exothermic peak of solidification, at $1.260^{\circ}$ and $1.280^{\circ} \mathrm{C}$. In the raw mixes with manganese appear several exothermic signals dues to 


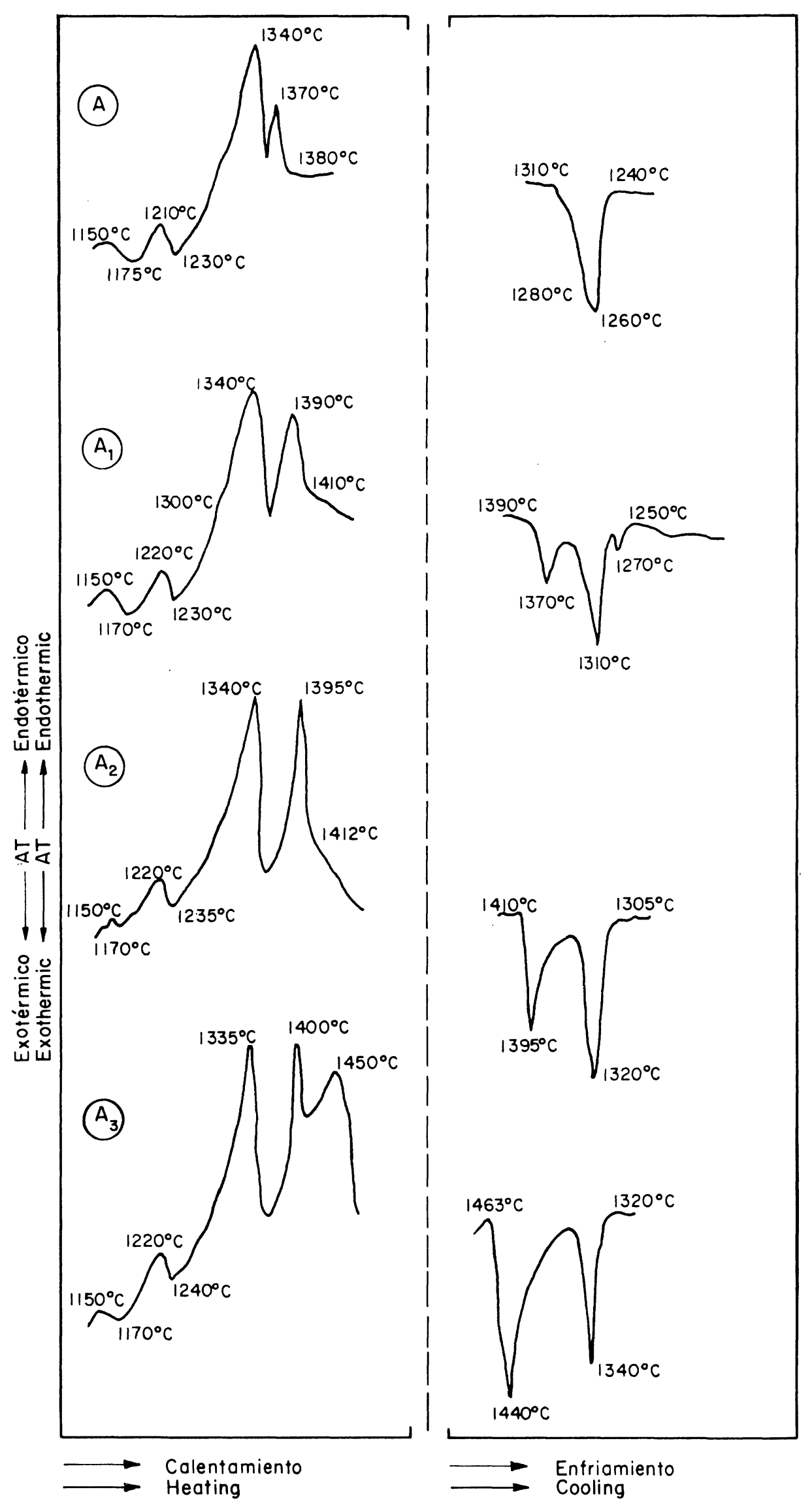

Fig. 1.-Curvas de ATD de los crudos $A, A_{1}, A_{2}$ y $A_{3}$.

Fig. 1.-DTA curves of raw mixes $A, A_{1}, A_{2}$ y $A_{3}$. 
líquidas, y cuyas temperaturas son en todos los casos superiores a las obtenidas para el crudo A.

\section{Difracción de rayos $X$}

En la Tabla III se muestran los resultados de DRX tras analizar por esta técnica los clínkeres obtenidos a $1.350^{\circ}, 1.400^{\circ}$ y $1.450^{\circ} \mathrm{C}$. solidification of certain liquid compositions, and whith temperature are, in all ocasions, high to obtained in raw mix $A$.

\section{$X$ ray diffraction}

Table III shows the x-ray powder data of clinkers obtained at $1.350^{\circ}, 1.400^{\circ}$ and $1.450^{\circ} \mathrm{C}$.

TABLA III (TABLE III)

Resultados de DRX de los clínkeres obtenidos a $1.350^{\circ} \mathrm{C}, 1.400^{\circ} \mathrm{C}$ y $1.450^{\circ} \mathrm{C}$ (X-Ray powder data of clinkers at $1.350^{\circ} \mathrm{C}, 1.400^{\circ} \mathrm{C}$ and $1.450^{\circ} \mathrm{C}$ )

\begin{tabular}{|c|c|c|c|c|c|c|c|c|c|}
\hline $\mathrm{T}\left({ }^{\circ} \mathrm{C}\right)$ & $\begin{array}{l}\text { CRUDO } \\
\text { RAW MIX }\end{array}$ & $\begin{array}{l}\text { ALITA } \\
\text { ALITE }\end{array}$ & $\mathrm{C}_{2} \mathrm{~S}$ & $\mathrm{C}_{3} \mathrm{~A}$ & $\mathrm{C}_{4} \mathrm{AF}$ & $\mathrm{CaO}$ & MgO & $\mathrm{C}_{2} \mathrm{AlMnO}_{5}$ & $2 \mathrm{CaO} \cdot \mathrm{MnO}_{2}$ \\
\hline \multirow{4}{*}{1350} & A & $+++{ }^{*}$ & + & ++ & + & ++ & + & - & - \\
\hline & $\mathrm{A}_{1}$ & ++ & + & + & ++ & +++ & + & - & ++ \\
\hline & $\mathrm{A}_{2}$ & ++ & ++ & O & ++ & +++ & + & - & ++ \\
\hline & $\mathrm{A}_{3}$ & + & ++ & o & +++ & + & + & + & + \\
\hline \multirow{4}{*}{1400} & A & +++ & + & ++ & 0 & + & + & - & - \\
\hline & $\mathrm{A}_{1}$ & +++ & + & + & + & + & + & + & + \\
\hline & $\mathrm{A}_{2}$ & ++ & + & - & + & - & + & ++ & + \\
\hline & $\mathrm{A}_{3}$ & + & ++ & - & + & - & + & +++ & ++ \\
\hline \multirow{4}{*}{1450} & A & $\dot{+}++$ & + & ++ & + & + & + & - & - \\
\hline & $\mathrm{A}_{1}$ & +++ & + & + & + & - & + & + & o \\
\hline & $A_{2}$ & +++ & + & - & $+\cdot$ & - & + & ++ & 0 \\
\hline & $\mathrm{A}_{3}$ & ++ & ++ & - & + & - & + & +++ & + \\
\hline
\end{tabular}

* Estos signos están directamente relacionados con la intensidad de las líneas de difracción, y en consecuencia con la cantidad de fase presente. Así: $+++=$ abundante; $++=$ moderado; $+=$ poco; $0=$ trazas $y-=$ no detectado.

* The sign are directly related to the intensity of the diffraction lines and nence to the quantity of the phase present. Thus: $+++=$ abundant, $++=$ moderate, $+=$ little, $0=$ traces, $-=$ not detected.

En esta tabla se puede apreciar como en todos los clínkeres obtenidos a partir de crudos con manganeso se forma el compuesto $2 \mathrm{CaO} . \mathrm{MnO}_{2}$, que es una fase fuertemente captadora de $\mathrm{CaO}$. También se desarrolla una fase ferrítica, que por difracción de rayos $X$ presenta sus reflexiones marcadamente
From this table, it is possible to see how, in all clinkers obtained from raw mixes with manganese, $2 \mathrm{CaO} . \mathrm{MnO}_{2}$ is formed, which is a strong spending $\mathrm{CaO}$ phase. A ferrite phase is, also, developed which shows some $x$-ray reflections significantly displaced in relation to those of traditional $C_{4} A F$ phase. 
desplazadas respecto a las de un $\mathrm{C}_{4} \mathrm{AF}$ tradicional.

Junto a las fases ya indicadas se origina otra nueva $\left(\mathrm{Ca}_{2} \mathrm{MnAlO}_{5}\right)$ cuyo contenido, tal y como se desprende de la tabla III, está directamente relacionado con el manganeso adicionado. Este compuesto ha sido caracterizado desde el punto de vista cristalográfico por T. Sakurai (3) en 1960. Este autor propuso sus líneas de difracción de rayos $\mathrm{X}$ y los parámetros de red de su estructura ortorrómbica.

Otra alteración en la composición mineralógica de los clínkeres con manganeso, es la disminución en el contenido de $\mathrm{C}_{3} \mathrm{~A}$. Los clínkeres con 2 y $5 \%$ de $\mathrm{Mn}$, a temperaturas superiores a $1.400^{\circ} \mathrm{C}$, carecen casi completamente de dicha fase.

\section{Microscopía óptica}

La característica más significativa observada al analizar por microscopía óptica de luz reflejada, los clínkeres obtenidos a partir de crudos con elevados contenidos en manganeso, es el incremento experimentado en la proporción de fase intersticial en relación al clínker $A$. Este fenómeno puede ser observado con claridad en las micrografías 1 y 2 , que corresponden a los clínkeres obtenidos a $1.450^{\circ} \mathrm{C}$ a partir de los crudos $\mathrm{A}$ y $\mathrm{A}_{3}$ respectivamente.

Así mismo, el estudio microscópico revela en los crudos con $\mathrm{Mn}$, una menor proporción de fase alítica, y consecuentemente una mayor cantidad de fase belita que en los clínkeres generados a igual temperatura a partir del crudo A. Estos resultados son coincidentes con los hallados por difracción de rayos $X$.

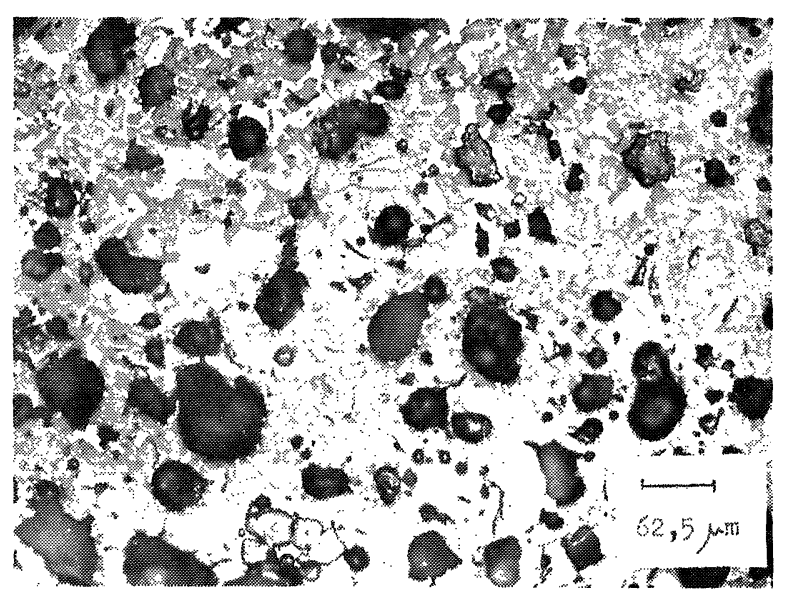

Micrografía 1.-Clínker obtenido a partir del crudo A a $1.450^{\circ} \mathrm{C}$.

Migrografía 1.-Clinker obtained from raw mix $A$ at $1.450^{\circ} \mathrm{C}$.
Another new phase, $\mathrm{Ca}_{2} \mathrm{AlMnO}_{5}$, is also generated (see Table III), and its content is directly related to the added manganese. This compound has been characterized, from a crystallogical point of view, by T. Sakurai (3) in 1960. This author proposed its $x$-ray diffraction lines and the cell parameters of its orthorombic structure.

As the mineralogical composition of the clinkers is altered by addition of manganese, the $\mathrm{C}_{3} A$ content also decreases. In clinkers with $2 \%$ and $5 \% \mathrm{Mn}$, at temperatures higher than $1.400^{\circ} \mathrm{C}$, there is an almost complete absence of this phase.

\section{Optical microscopy}

The main characterististic detected analyzing by this technique, the clinkers obtained from raw mixes with high manganese contents, is the increase of interstitial phase proportions in relation to clinker $A$. This phenomenon can be shown in micrographs 1 and 2, which correpond to clinkers obtained at $1.450^{\circ} \mathrm{C}$, from $\mathrm{A}$ and $\mathrm{A}_{3}$ raw mixes, respectively.

Likewise, the microscopic study reveals, in raw mixes with $\mathrm{Mn}$, a less proportion of alitic phase, and consequently a high amount of belitic phase than clinkers obtained, at same temperature, from raw mix A. This results are coincident with those obtained from x-ray data.

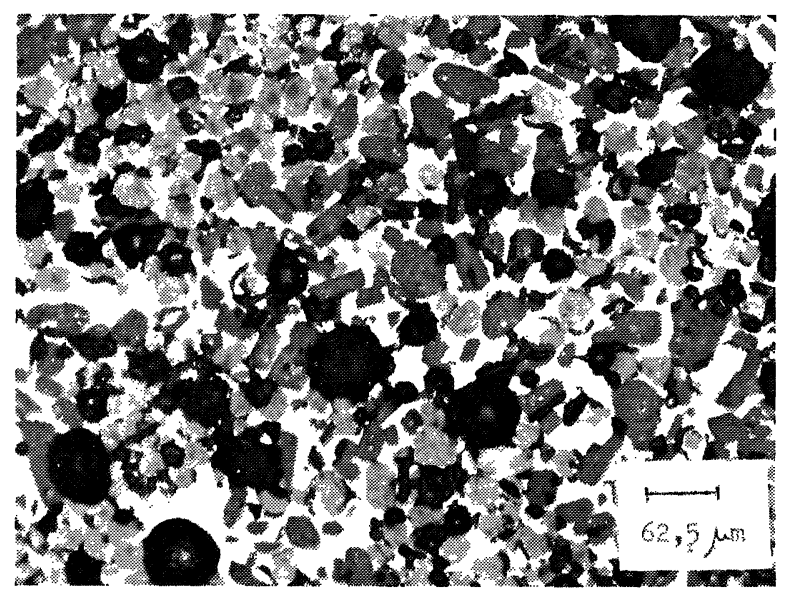

Micrografía 2.-Clínker obtenido a partir del crudo $A_{3}$ a $1.450^{\circ} \mathrm{C}$.

Micrografía 2.-Clinker obtained from raw mix $A_{3}$ at $1.450^{\circ} \mathrm{C}$.

MATERIALES DE CONSTRUCCION, Vol. 38, n.॰210, abril/mayo/junio 1988 


\section{Análisis de $\mathrm{CaO}$ libre de las muestras templadas}

La figura 2 representa la variación en el contenido de $\mathrm{CaO}$ libre (medido por el método del etilenglicol) en los clínkeres obtenidos a $1.350^{\circ}, 1.400^{\circ}$ y $1.450^{\circ} \mathrm{C}$. En dicha figura se puede observar como a $1.400^{\circ} \mathrm{C}$ se produce un descenso muy brusco en el contenido de $\mathrm{CaO}$ libre en todos los clínkeres que contienen manganeso.

\section{Analysis of free $\mathrm{CaO}$ of quenching samples}

Figure 2 shows the variation in the content of free $\mathrm{CaO}$ (from ethilen-glicol method) in the clinkers obtained at $1.350^{\circ}, 1.400^{\circ}$ and $1.450^{\circ} \mathrm{C}$. In this figure, a sharp drop in free $\mathrm{CaO}$ can be observed at $1.400^{\circ} \mathrm{C}$, in all clinkers which contain manganese.

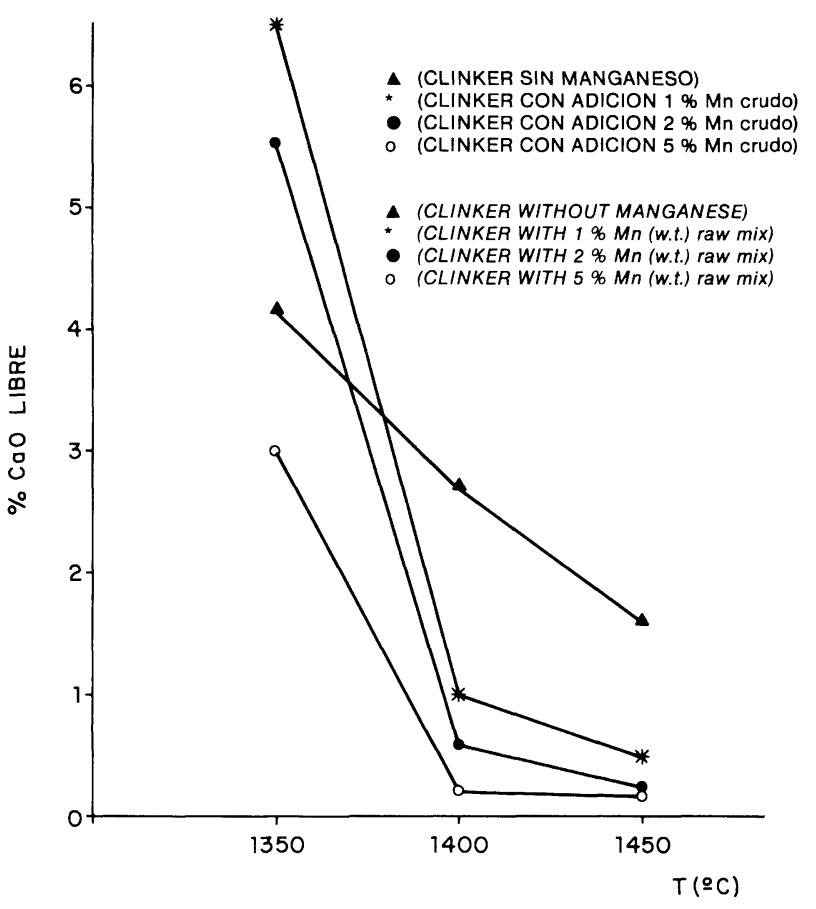

Fig. 2.-Variación en el contenido de $\mathrm{CaO}$ libre en función de la temperatura en los clínkeres obtenidos a partir de los crudos $A, A_{1}, A_{2}$ y $A_{3}$.

\section{DISCUSION}

Ciertas escorias de alto horno poseen contenidos elevados en óxidos de manganeso que en algunos casos superan el $3 \%$. Se consideró, por ello, interesante conocer el efecto que dicho elemento provocaba sobre la reactividad del crudo, ya que su introducción como componentes minoritarios podria afectar sensiblemente a la reactividad de los crudos y muy especialmente al proceso global de clinkerización.

Las curvas de ATD de los crudos estudiados (ver figura 1) muestran un comportamiento térmico diferente entre el crudo $\mathrm{A}$ y los restantes que contienen manganeso.

Los cuatro crudos presentan una señal endotérmica hacia $1.340^{\circ} \mathrm{C}$, que muy
Fig. 2-Variation in the free lime content of the clinkers obtained from raw mixes $A, A_{1}, A_{2}$ and $A_{3}$, with temperature.

\section{DISCUSSION}

Certain blast-furnace slags have high contents in manganese oxides, that in some occasions can be superior $3 \%$. For this reason, it was considered interesting to know the effect of this element on the reactivity of raw mix; affect the reactivity of raw mixes and more specifically on the clinkering process.

The DTA curves of studied raw mixes (see figure 1) show a thermical behaviour so different between raw mix $A$ and those which contain manganese.

The four raw mixes have an endothermic signal at $1.340^{\circ} \mathrm{C}$, which is due, probably, a meltings 
probablemente corresponde a la temperatura de fusión de una composición próxima a la del eutéctico cuaternario $\mathrm{C}_{3} \mathrm{~S}-\mathrm{C}_{2} \mathrm{~S}-\mathrm{C}_{3} \mathrm{~A}-\mathrm{C}_{4} \mathrm{AF}$ a $1.338^{\circ} \mathrm{C}$. Sin embargo, aunque la temperatura de dicha señal no experimenta modificación, sí se observa un incremento en la intensidad de la misma cuando hay manganeso presente. Esto puede ser debido a la existencia de una mayor cantidad de fase ferrítica que contiene manganeso en disolución sólida. En trabajos precedentes (9) se ha demostrado que el manganeso puede incorporarse a la estructura ortorrómbica del $\mathrm{C}_{4} \mathrm{AF}$ hasta un límite máximo de un $6,7 \%$ en peso, formando una disolución sólida de tipo continuo.

Una segunda señal endotérmica situada en $1.370^{\circ} \mathrm{C}$ en el crudo $\mathrm{A}$, se desplaza a temperaturas superiores $\left(1.390^{\circ}-1.400^{\circ} \mathrm{C}\right)$ en los crudos que contienen manganeso. Así mismo, se observa un incremento en la intensidad de dicha señal según aumenta el porcentaje de $\mathrm{Mn}$ presente. Estas observaciones demuestran, obviamente, que en esa fisión está interviniendo de manera destacada dicho elemento. En el crudo $A_{3}$ aparece una tercera señal endotérmica cuyo máximo se sitúa próximo a $1.450^{\circ} \mathrm{C}$. Por difracción de rayos $X$ (ver tabla III) se identifica la existencia del compuesto $\mathrm{Ca}_{2} \mathrm{AlMnO}_{5}$ cuyo contenido se ve fuertemente incrementado en los clínkeres obtenidos a partir del crudo $A_{3}$. Según Lea y col. (1) este compuesto funde congruentemente a $1.478^{\circ} \mathrm{C}$; por lo que la señal de $1.450^{\circ} \mathrm{C}$ podría ser debida a la fusión de este compuesto junto con el de alguna otra fase.

La clínkerización de los crudos estudiados en el presente trabajo se realizó a las temperaturas de $1.350^{\circ}, 1.400^{\circ}$ y $1.450^{\circ} \mathrm{C}$. A estas temperaturas, todos los clínkeres obtenidos a partir de crudos conteniendo manganeso presentan algunas diferencias mineralógicas respecto a un clínker tradicional. Se forma, a todas las temperaturas de tratamiento, el compuesto $2 \mathrm{CaO} \cdot \mathrm{MnO}_{2}$, que es una fase fuertemente captadora de $\mathrm{CaO}$. También se desarrolla una fase ferrítica cuyas líneas de difracción de rayos $X$ están marcadamente desplazadas respecto a las del $\mathrm{C}_{4} \mathrm{AF}$. Estas alteraciones se ha comprobado (9) que son debidas a la introcucción de $\mathrm{Mn}^{3+}$ en las posiciones del $\mathrm{Fe}^{3+}$ y $\mathrm{Al}^{3+}$ en la estructura cristalina de la fase ferrítica, en una proporción próxima al 6,7 \% en peso de $\mathrm{Mn}$.

La figura 2 muestra la variación en el contenido de $\mathrm{CaO}$ libre de todos los clínkeres obtenidos en relación con la temperatura de tratamiento. El descenso observado en el contenido de $\mathrm{CaO}$ a $1.400^{\circ} \mathrm{C}$, en los clínkeres generados a partir de crudos con manganeso, parece no ser debido a una aceleración en el of compositions close to the cuaternary eutectic $C_{3} S-C_{2} S-C_{3} A-C_{4} A F$ at $1338^{\circ} \mathrm{C}$. However, though the temperature of this signal do not experiment alteration in all raw mixes, it is possible to see an increase in its intensity when manganese is present. This can be due to the existence of a high amount of ferritic phase which contain manganese in solid solution. In precedent studies (9) it was proved that the manganese is incorporated to orthorombic structure of $\mathrm{C}_{4} \mathrm{AF}$ until a maximun value of $6,7 \% w t$, forming a continuous solit solution.

The second endothermic signal at $1.370^{\circ} \mathrm{C}$ in raw mix $A$ goes at high temperature $\left(1.390^{\circ}-\right.$ $1.400^{\circ} \mathrm{C}$ ) in raw mixes with contain manganese. Likewise, it was observed an increase in the intensity of this signal according to increase the proportion of $\mathrm{Mn}$ present. These observations show, that in this melting the manganese is performing. In raw mix $A_{3}$ appears a third endothermic peak whch maximun is at $1.450^{\circ} \mathrm{C}$. By x-ray diffraction (see Table (II) it is possible identifie the presence of compound, $\mathrm{Ca}_{2} \mathrm{AlMnO}_{5}$, which amount, it is increased in clinkers obtained from raw mix $A_{3}$. As Lea and al (1) this compound melts congruently at $1.478^{\circ} \mathrm{C}$, thus the peak at $1.450^{\circ} \mathrm{C}$ could be due to the melting of this compound with another phase.

The clinkerization of the raw mixes with manganese was carried out at $1.350^{\circ}, 1.400^{\circ}$ and $1.450^{\circ} \mathrm{C}$. All the clinkers obtained at these temperatures showed some mineralogical differences in relation to a traditional clinker. At all temperatures the compound $2 \mathrm{CaO} . \mathrm{MnO}_{2}$ is formed. This a phase strongly spent $\mathrm{CaO}$ phase. A ferritic phase is, also, developed which shows some $x$-ray reflections significantly displaced in relation to those of $C_{4} A F$. These alterations are due to introduction of $\mathrm{Mn}^{3+}$ in the $\mathrm{Fe}^{3+}$ and $\mathrm{Al} 3+$ positions into the crystalline structure of the ferritic phase (9), in a proportion close to $6,7 \%$ wt $M n$.

Figure 2 shows the variation in the content of free $\mathrm{CaO}$ in all clinkers obteined.

The drop in the free $\mathrm{CaO}$ at $1.400^{\circ} \mathrm{C}$ in the clinkers obtained from raw mix with manganese are not due an acceleration in the formation process of alite (the results from $x$ - 
proceso de formación de alita (tal y como se deduce de los resultados encontrados por difracción de rayos $X$ y microscopía óptica); sino que por el contrario se produce un descenso acusado en sus contenidos según se incrementa el porcentaje de $\mathrm{Mn}$ presente (ver tabla III). Sin embargo, sí se advierte que esas reducciones drásticas en los contenidos de $\mathrm{CaO}$ libre son simultáneas a la formación del compuesto $\mathrm{Ca}_{2} \mathrm{AlMnO}_{5}$. Esta fase se forma a $1.400^{\circ} \mathrm{C}$ en los clínkeres con 1 y $2 \%$ de $\mathrm{Mn}$; y a $1.350^{\circ} \mathrm{C}$ cuando se ha adicionado un $5 \%$ de $\mathrm{Mn}$. Como se puede apreciar en la figura 2 este último clínker tiene un contenido en $\mathrm{CaO}$ libre marcadamente inferior al de los restantes a igual temperatura.

Otra alteración mineralógica observada en los clínkeres obtenidos a partir de crudos con elevados porcentajes en manganeso, es la disminución en el contenido de $\mathrm{C}_{3} \mathrm{~A}$. Este fenómeno ya fue observado por Kennerly (2); y parece ser debido a la captación de $\mathrm{Al}^{3+}$ preciso para la formación de la fase $\mathrm{Ca}_{2} \mathrm{AlMnO}_{5}$.

El incremento en la reactividad y la mejora de la aptitud a la cocción observados en los crudos con manganeso es debido, a la disminución del grado de saturación de cal (LSF) real, por la introducción en el crudo de otros componentes (óxido de manganeso), que son capaces de combinarse con ciertos óxidos $\left(\mathrm{Al}_{2} \mathrm{O}_{3}\right.$ y $\left.\mathrm{CaO}\right)$ para formar fases ricas en $\mathrm{CaO}$ $\left(2 \mathrm{CaO} \mathrm{MnO}_{2}\right.$ y $\mathrm{Ca}_{2} \mathrm{AlMnO}_{5}$ ), y de entrar en disolución sólida en fases tradicionales como son la ferrítica, alítica, etc. (10). Así mismo, la presencia de manganeso provoca un descenso notable en los módulos $\mathrm{Ms}$ y $\mathrm{Mf}$, ya que hay que tener en cuenta que el $\mathrm{Mn}_{2} \mathrm{O}_{3}$ puede ocupar las posiciones del $\mathrm{Fe}_{2} \mathrm{O}_{3} \mathrm{y}$ $\mathrm{Al}_{2} \mathrm{O}_{3}$ en la fase ferrítica.

La disminución de estos módulos (Ms y Mf) tiene como consecuencia un incremento en el contenido en fase líquida. Utilizando los denominados diagramas de clnkerización (11) y teniendo en cuenta los contenidos de $\mathrm{Fe}_{2} \mathrm{O}_{3}$ y $\mathrm{Al}_{2} \mathrm{O}_{3}$ en el clínker obtenido a partir del crudo $\mathrm{A}$, a $1.400^{\circ} \mathrm{C}$, se deduce que el porcentaje de fase intersticial de dicho clínker se sitúa próximo al $25 \%$.

Dado que el manganeso se ha comprobado que tiene un comportamiento muy similar al del hierro (formación del compuesto $\mathrm{Ca}_{2} \mathrm{AlMnO}_{5}$ que es isomorfo a la fase ferrítica del clínker del cemento portland, $\mathrm{Ca}_{2} \mathrm{AIFeO}_{5}$ ); puede ser considerado un fundente como el $\mathrm{Al}_{2} \mathrm{O}_{3}$ y el $\mathrm{Fe}_{2} \mathrm{O}_{3}$. Llevando, por tanto, a los diagramas de clinkerización, a $1.400^{\circ} \mathrm{C}$, el porcentaje de $\mathrm{Al}_{2} \mathrm{O}_{3}$ y el de $\left(\mathrm{Fe}_{2} \mathrm{O}_{3}+\mathrm{Mn}_{2} \mathrm{O}_{3}\right)$, del clínker con $1 \%$ de $\mathrm{Mn}$, se encuentra que la proporción de fase fundida a esta temperatura está próxima al $29 \%$. ray and optical microscopy data show this); on the contrary, the alite content, decreases as the percentage of manganese increases (see Table (II). However, these drastic reductions in free lime content are simultaneous with the formation of $\mathrm{Ca}_{2} \mathrm{AlMnO}_{5}$. This phase is formed at $1.400^{\circ} \mathrm{C}$ in clinkers with 1 and $2 \% \mathrm{Mn}$; and at $1.350^{\circ} \mathrm{C}$ in the clinkers with $5 \% \mathrm{Mn}:$ In figure 2 one can observe that last clinker has a free lime content much less that of the other clinkers at the same temperature.

Another alteration in the mineralogical composition of the clinkers with manganese, is the decrease in $C_{3} A$ content. This phenomenon has also been observed by Kennerly (2); and it would be due to the captation of $\mathrm{Al}^{3+}$ to form $\mathrm{Ca}_{2} \mathrm{AlMnO}_{5}$ phase.

The increase in the reactivity and the improvement in the burnability of the raw mixes with manganese is due to the decrease of lime saturation factor (LSF), by the introduction of other components (manganese oxides) which are able to combine with other oxides $\left(\mathrm{Al}_{2} \mathrm{O}_{3}\right.$ and $\left.\mathrm{CaO}\right)$ to form phases rich in $\mathrm{CaO}$ (2 $\mathrm{CaO}_{\mathrm{MnO}}$ and $\mathrm{Ca}_{2} \mathrm{AlMnO}_{5}$ ). Also these manganese oxides can go into solid solution in the ferritic phases, alitic phases, etc. (10). The presence of manganese also causes a notable decrease of $\mathrm{Ms}$ and $\mathrm{Mf}$ since $\mathrm{Mn}_{2} \mathrm{O}_{3}$ can occupy the positions of $\mathrm{Fe}_{2} \mathrm{O}_{3}$ and $\mathrm{Al}_{2} \mathrm{O}_{3}$ in the ferritic phase.

The decrease of these modula (Ms and Mf) bring about an increase in the content of the liquid phase. From the diagrams of clinkerizations (11) and considering the contents of $\mathrm{Fe}_{2} \mathrm{O}_{3}$ and $\mathrm{Al}_{2} \mathrm{O}_{3}$ in the clinker from raw mix $A$ obtained at $1.400^{\circ} \mathrm{C}$, the percentage of the liquid phase can be estimated to be about $25 \%$.

As the manganese has a behaviour very similar to the iron (formation the compound $\mathrm{Ca}_{2} \mathrm{AlMnO}_{5}$ which is isomorphic with the ferritic phase in the portland cement clinker, $\mathrm{Ca}_{2} \mathrm{AlFeO}_{5}$ ); can be considered as a flux like $\mathrm{Fe}_{2} \mathrm{O}_{3}$ and $\mathrm{Al}_{2} \mathrm{O}_{3}$. Therefore, considering the diagrams of clinkerization at $1.400^{\circ} \mathrm{C}$, the percentage of $\mathrm{Al}_{2} \mathrm{O}_{3}$ and $\left(\mathrm{Fe}_{2} \mathrm{O}_{3}+\mathrm{Mn}_{2} \mathrm{O}_{3}\right)$ from the clinker with $1 \%$ of $\mathrm{Mn}$, the proportion of the liquid phase at this temperature is found to be close to $29 \%$. Comparing microscophs 1 and 2, which correspond to the clinkers obtained 
Comparando las micrografías 1 y 2 , que corresponden a los clínkeres obtenidos a partir de los crudos $A$ y $A_{3}$ a $1.450^{\circ} \mathrm{C}$, se puede observar este incremento en el contenido en fase líquida motivada por la presencia de manganeso.

Las propiedades de la fase líquida pueden verse modificadas por la presencia de ciertos elementos como el manganeso. Timashew (12) indica que este elemento, debido a su carácter debilmente ácido, disminuye la viscosidad del líquido lo que favorece la movilidad iónica, y consecuentemente, se incrementa la velocidad de formación del $\mathrm{C}_{3} \mathrm{~S}$.

\section{CONCLUSIONES}

Las principales conclusiones extraibles del presente trabajo son:

- Cuando hay elevados contenidos de manganeso en los crudos, se produce una modificación significativa de los constituyentes mineralógicos tradicionales del clínker del cemento portland. Se desarrollan las fases no tradicionales $2 \mathrm{CaO} . \mathrm{MnO}_{2}$ y $\mathrm{Ca}_{2} \mathrm{AlMnO}_{5}$, pudiéndose inhibir la formación de aluminato tricálcico.

- Las escorias de alto horno con elevados contenidos en manganeso son potencialmente válidas en la fabricación de crudos de cemento, aunque hay que tener en cuenta en la preparación de dichos crudos que la presencia de manganeso modifica las expresiones del grado de saturación de cal (LSF), módulo silícico (Ms) y módulo de fundentes (Mf). from $A$ and $A_{3}$ raw mixes at $1.450^{\circ} \mathrm{C}$; it is possible to observe this increase in the the content of liquid phase due to the presence of manganese is observed.

The properties of the liquid phase of portland clinker can be modified by presence of certain elements, such as manganese. Timashev (12) says that this element, due to its slight acid character, decreases the viscosity of the liquid, which increases the ionic mobility and consequently the rate of the formation of $\mathrm{C}_{3} \mathrm{~S}$.

\section{CONCLUSIONS}

The main conclusions deduced from the present work are:

- Where there are high contents of manganese in cement raw mixes, a significant modification of the mineralogical composition of the portland clinker occurs. Unusual phases such as $2 \mathrm{CaO} . \mathrm{MnO}_{2}$ and $\mathrm{Ca}_{2} \mathrm{AlMnO}_{5}$ develop; and the $\mathrm{C}_{3} \mathrm{~A}$ formation may also be inhibited.

- Blast-furnace slags with high contents of manganese are potentially useful as cement-making raw materials; although the fact that presence of manganese will modify the expresions of the lime saturation factor (LSF), silica modulus (MS) and alumina modulus (Mf) must be taken into account

\section{BIBLIOGRAFIA}

(1) LEA, F. P., DESCH, C. H.: "The Chemistry of Cement and Concrete". 2. " Ed. pp. 76-78 (1956).

(2) KENNERLY, R. A.: Cem. Concr. Res. Vol. 7, pp. 565-574 (1977).

(3) SAKURAI, T.: Review of the Fourteenth General Meeting. Japan. Cement Engineering Association (Tokio), pp. 23-24 (1960).

(4) AKATSU, K., MONNA, I.: Review of the 20th. General Meeting. Japan Cement Engineering (Tokio), pp. 41-42 (1966).

(5) VOlKova, I. S., DOGANDZHIEVA, R. G.: VII Int. Cong. Chem. Cem. (París), pp. 79-83 (1980).

(6) VOLKOV, V., SITCHIOW, M. M., GIGOVA, L., NIKIFOROV, Y. V.: VII Int. Cong. Chem. Cem. (París), pp. $95-98$ (1980).

(7) Pliego de Prescripciones para la Recepción de Conglomerantes RC-75. España (1975).

(8) TAKASHIMA, S.: Sement. Giujitsu Nempo XII, pp. 12-13 (1958).

(9) PUERTAS, F., GLASSER, F. P.: Advances in Cement Research, Vol. 1, n.0 1, pp. $31-34$ (1987).

(10) PUERTAS, F.: Tesis Doctoral. Universidad Autónoma de Madrid (1987).

(11) HeRATh BANDA, R. H., Glasser, F. P.: Cem. Concr. Res., Vol. 8, pp. 319 (1978).

(12) TIMASHeV, V. V.: VII Int. Cong. Chem. Cem. (París). Vol. (I), pp. 1-19 (1980). 